\title{
A GREEN CHEMICAL APPROACH FOR NITRATION OF AROMATIC COMPOUNDS
}

\author{
Arpita Dugar ${ }^{1}$, Anil Kumar ${ }^{1}$, Rameshwar Ameta ${ }^{2 *}$, Suresh C. Ameta ${ }^{1}$ \\ ${ }^{1}$ Photochemistry Laboratory, Department of Chemistry, M. L. Sukhadia University, \\ Udaipur, 313002 (Raj.) India \\ ${ }^{2}$ Government Meera Girls College, Udaipur - 313002 (Raj.) India \\ ameta_ra@yahoo.com//anilchohadia@yahoo.co.in
}

\begin{abstract}
Photochemical aromatic nitration of phenol and salicylic acid has been carried out in the presence of UV radiations and formation of products has been observed spectrophotometrically. The effect of various operating variables like $\mathrm{pH}$, concentration of nitrite ion, formate ion, phenol and salicylic acid, etc. on the rate of the reaction has also been observed. A tentative mechanism involving $\mathrm{NO}_{2}{ }^{\bullet}$ radicals has been proposed for photochemical nitration of phenol and salicylic acid.
\end{abstract}

Key words: photochemical nitration; aromatic; phenol; salicylic acid; ecofriendly

\section{ЕКОЛОШКИ ХЕМИСКИ ПРИСТАП КОН НИТРИРАЊЕ АРОМАТИЧНИ СОЕДИНЕНИЈА}

\begin{abstract}
Изведено е фотохемиско ароматично нитрирање на фенол и салицилна киселина во присуство на УВ зрачење и добиените продукти се наблјудувани спектрофотометриски. Испитани се влијанијата на различни оптимизациони параметри како што се $\mathrm{pH}$, концентрациите на нитритни и формијатни јони, фенол, салицилна киселина итн. Следена е и брзината на реакцијата. Предложен е привремен механизам кој ги вклучува радикалите на $\mathrm{NO}_{2}^{\bullet}$ при фотохемиското нитрирање на фенолот и салицилната киселина.
\end{abstract}

Клучни зборови: фотохемиско нитрирање; ароматичен; фенол; салицилна киселина; еколошки прифатлив

\section{INTRODUCTION}

Aromatic compounds undergo electrophilic substitution reactions due to high electron density of the benzene ring. These reactions are difficult and proceed under drastic conditions such as use of fuming nitric acid, high temperature, refluxing, etc. which create pollution and hazardous environment. Therefore, it has been proposed to develop an alternate green chemical path ways like photochemical, photocatalytic, microwave irradiation, etc. to synthesize nitro compounds under ambient conditions.

The destruction of hazardous organic pollutant in waste streams, drinking water and industrial effluent can be achieved through the use of Advance Oxidation Processes (AOPs). These are chemical oxidant ion techniques, which are able to produce in situ reactive free radicals, mainly hydroxyl radicals $\left({ }^{\circ} \mathrm{OH}\right)$ by means of different reacting systems. These processes are capable of degrading almost all organic contaminants.

The concept of AOPs was originally established by Glaze et al. [1] as "Oxidation Processes which generated hydroxyl radicals in sufficient quantity to affect water treatment". Photonitration of phenol by tetranitromethane under visible light was investigated by Selzer et al. [2]. Vione et al. [3] used phenol as a model aromatic molecule and $\mathrm{TiO}_{2}$ as photocatalyst to carry out aromatic photochemical nitration in homogeneous and heterogeneous aqua systems. Photonitration of monuron induced by nitrate and nitrite ions in water has been reported by Nelieu et al. [4] while Lalitha 
and Sivakumar [5] suggested a simple and effective solid-supported reagent for nitration of phenols and their derivatives on zeolite $\mathrm{H}$-Y-supported copper(II)nitrate.

Photochemically induced nitration and hydroxylation of organic aromatic compounds in the presence of nitrate or nitrite in ice were observed by Nina et al. [6]. Nitration of aromatic compound on silica sulphuric acid was investigated by Mohammed Ali Zolfigol et al. [7]. Varma et al. [8] investigated a solvent-free synthesis of $p$-nitrostyrene derived from styrene and its substituted derivatives using inexpensive 'doped' clay reagents, clayfen and clayan.

Beitz et al. [9] has investigated the photoreactions of nitrate and nitrite ions with selected azaarenes in water. Negav et al. [10] carried out direct N-nitration of bis(trifloromethyl) containing 2-azanorbornanes. Kono et al. [11] observed that catalase catalyzes peroxynitrite mediated phenolic nitration of 4-hydroxyphenylacetic acid. Cynide, azide and 3-amino-1,2,4-triazole inhibited the nitration.

Vapour phase nitration of toluene using nitric acid and molecular modeling studies over betazeolite was observed by Dagade et al. [12]. Desrocheset et al. [13] reported nitration of thiacalix [4] arene using nitrosonium nitrate complex, whereas nitration of [3,3]- and [3,3,3]-metacyclophanes through space electronic between two or three benzene rings was carried out by Yamato et al. [14]. Usui et al. [15] suggested the photochemical nitration of benzoic acid derivatives by irradiation to nitrate ions. The photolysis of nitrite and nitrous which is a relevant source of $\mathrm{OH}^{*}$ in the environment [16], but it also yields nitrogen dioxide [17].

$$
\begin{gathered}
\mathrm{NO}_{2}{ }^{-}+\mathrm{H}^{+} \longrightarrow \mathrm{NO}^{\bullet}+\mathrm{OH}^{\bullet} \\
\mathrm{NO}_{2}{ }^{-}+\mathrm{OH}^{\bullet} \longrightarrow \mathrm{NO}_{2}{ }^{-}+\mathrm{OH}^{-}
\end{gathered}
$$

\section{EXPERIMENTAL}

$0.09411 \mathrm{~g}$ of phenol was dissolved in $100 \mathrm{ml}$ of doubly distilled water and $0.069 \mathrm{~g}$ of $\mathrm{NaNO}_{2}$ in $100 \mathrm{ml}$ of doubly distilled water. Also, $0.068 \mathrm{~g}$ of sodium formate was dissolved in $100 \mathrm{ml}$ of doubly distilled water. All the three solutions were used as stock solutions. $8.0 \mathrm{ml}$ of phenol solution, $6.0 \mathrm{ml}$ of $\mathrm{NaNO}_{2}$ solution and $0.8 \mathrm{ml}$ of sodium formate solution were mixed, so that the concentration of phenol, sodium nitrite and sodium formate in the reaction mixture was $3.2 \cdot 10^{-3} \mathrm{M}, 2.4 \cdot 10^{-3} \mathrm{M}$ and $3.2 \cdot 10^{-4} \mathrm{M}$, respectively.

Similarly, $0.138 \mathrm{~g}$ of salicylic acid was dissolved in $100 \mathrm{ml}$ of doubly distilled water, $0.069 \mathrm{~g}$ of $\mathrm{NaNO}_{2}$ in $100 \mathrm{ml}$ of doubly distilled water and $0.068 \mathrm{~g}$ of sodium formate was dissolved in $100 \mathrm{ml}$ of doubly distilled water. All the three solutions were used as stock solutions. $7.0 \mathrm{ml}$ of salicylic acid solution, $6.0 \mathrm{ml}$ of $\mathrm{NaNO}_{2}$ solution and $0.6 \mathrm{ml}$ of sodium formate solutions were mixed, so that the concentration of salicylic acid, sodium nitrite and sodium formate in the reaction mixture was $2.8 \cdot 10^{-3} \mathrm{M}, 2.4 \cdot 10^{-3} \mathrm{M}$ and $2.4 \cdot 10^{-4} \mathrm{M}$, respectively.

The reaction mixture was exposed to the ultraviolet lamp of $254 \mathrm{~nm}$. The optical density of the solution at various time intervals was determined at $\lambda_{\max }=400 \mathrm{~nm}$ and $390 \mathrm{~nm}$ of phenol and salicylic acid with the help of spectrophotometer (Systronics model 106). Some control experiments were also carried out and it was concluded that light is necessary for photochemical nitration of phenol and salicylic acid. The products were identified by gas chromatography combined with mass spectroscopy GC-MS (Perkins Elmer Auto System $\mathrm{XL})$.

\section{RESULTS AND DISCUSSION}

The results of a typical run for photochemical nitration are shown in Table 1. It was observed that absorption (A) increases with time exposure for both phenol and salicylic acid indicating the formation of nitro products but after optimum absorption (A) it becomes almost constant. A plot of $1+\log A$ versus exposure time was linear and hence, the reaction follows pseudo-first order kinetics and the rate constant was determined by the expression $k=2.303 \cdot$ slope.

\section{Effect of $p H$}

The $\mathrm{pH}$ of medium is likely to affect the rate of reaction. The effect of $\mathrm{pH}$ variation was investigated in the $\mathrm{pH}$ range of $4-7.5$ and the results are summarized in Table 2. The rate of reaction increases on increasing $\mathrm{pH}$ up to 5.5 for phenol and 5.0 for salicylic acid. There after, there is an adverse effect on the rate of reaction on increasing the $\mathrm{pH}$. 
Table 1

Typical run for phenol and salicylic acid

\begin{tabular}{|c|c|c|}
\hline \multicolumn{2}{|c|}{$\begin{array}{l}\text { Phenol } \\
{[\text { Phenol }]=3.2 \cdot 10^{-3} \mathrm{M}} \\
\text { pH }=5.5 \\
\mathrm{NaNO}_{2}=2.4 \cdot 10^{-3} \mathrm{M} \\
\mathrm{HCOONa}=3.2 \cdot 10^{-4} \mathrm{M}\end{array}$} & \multirow[t]{2}{*}{$\begin{array}{l}\text { Salicylic acid } \\
{[\text { Salicylic acid }]=2.8 \cdot 10^{-3} \mathrm{M}} \\
\mathrm{pH}=5.0 \\
\mathrm{NaNO}_{2}=2.4 \cdot 10^{-3} \mathrm{M} \\
\frac{\mathrm{HCOONa}=2.4 \cdot 10^{-4} \mathrm{M}}{1+\log \mathrm{A}(\text { Salicylic acid })}\end{array}$} \\
\hline Time (min) & $1+\log \mathrm{A}($ Phenol $)$ & \\
\hline 10 & 0.228 & - \\
\hline 15 & 0.439 & 0.0086 \\
\hline 20 & 0.560 & 0.0969 \\
\hline 25 & 0.721 & 0.2227 \\
\hline 30 & 0.903 & 0.3053 \\
\hline 35 & 1.078 & 0.396 \\
\hline 40 & 1.103 & 0.4768 \\
\hline 45 & 1.124 & 0.5528 \\
\hline 50 & 1.129 & 0.5852 \\
\hline 55 & 1.135 & 0.6037 \\
\hline 60 & 1.141 & 0.6097 \\
\hline 65 & 1.149 & 0.6131 \\
\hline 70 & 1.156 & 0.6202 \\
\hline 75 & 1.169 & 0.6265 \\
\hline 80 & 1.178 & 0.6315 \\
\hline 85 & 1.197 & 0.6368 \\
\hline 90 & 1.198 & 0.6412 \\
\hline 95 & 1.206 & 0.6521 \\
\hline 100 & 1.208 & 0.6602 \\
\hline 105 & - & 0.6678 \\
\hline \multirow[t]{2}{*}{110} & - & 0.6689 \\
\hline & $\begin{array}{l}k_{1}=1.28 \cdot 10^{-3} \mathrm{~s}^{-1} \\
k_{2}=7.67 \cdot 10^{-5} \mathrm{~s}^{-1}\end{array}$ & $\begin{array}{l}k_{1}=7.086 \cdot 10^{-4} \mathrm{~s}^{-1} \\
k_{2}=5.575 \cdot 10^{-5} \mathrm{~s}^{-1}\end{array}$ \\
\hline
\end{tabular}

Table 2

\section{Effect of $p H$}

\begin{tabular}{|c|c|c|}
\hline \multicolumn{2}{|c|}{$\begin{array}{l}\text { Phenol } \\
{[\text { Phenol }]=3.2 \cdot 10^{-3} \mathrm{M}} \\
\mathrm{NaNO}_{2}=2.4 \cdot 10^{-3} \mathrm{M} \\
\mathrm{HCOONa}=3.2 \cdot 10^{-4} \mathrm{M}\end{array}$} & $\begin{array}{l}\text { Salicylic acid } \\
{[\text { Salicylic acid }]=2.8 \cdot 10^{-3} \mathrm{M}} \\
\mathrm{NaNO}_{2}=2.4 \cdot 10^{-3} \mathrm{M} \\
\mathrm{HCOONa}=2.4 \cdot 10^{-4} \mathrm{M}\end{array}$ \\
\hline $\mathrm{pH}$ & $k \cdot 10^{4} \mathrm{~s}^{-1}($ Phenol $)$ & $k \cdot 10^{3} \mathrm{~s}^{-1}$ (Salicylic acid) \\
\hline 4.0 & - & 2.60 \\
\hline 4.5 & - & 6.13 \\
\hline 5.0 & 5.65 & 7.08 \\
\hline 5.5 & 12.79 & 2.89 \\
\hline 6.0 & 9.15 & 2.61 \\
\hline 6.5 & 8.85 & - \\
\hline 7.0 & 7.90 & - \\
\hline 7.5 & 6.90 & - \\
\hline
\end{tabular}

Initially, when $\mathrm{pH}$ is increased, the reaction rate also increases because $\mathrm{N}_{2} \mathrm{O}_{4}$ and $\mathrm{N}_{2} \mathrm{O}_{3}$ are easily generated,

$$
\begin{aligned}
& \mathrm{NO}_{2}+\mathrm{NO}^{\bullet} \longrightarrow \mathrm{N}_{2} \mathrm{O}_{3} \\
& \mathrm{NO}_{2}+\mathrm{NO}_{2} \longrightarrow \longrightarrow \mathrm{N}_{2} \mathrm{O}_{4}
\end{aligned}
$$

which are considered to be active species for photonitration of aromatic systems

$$
\begin{array}{r}
\mathrm{N}_{2} \mathrm{O}_{3}+\mathrm{ArH} \longrightarrow \mathrm{ArNO}+\mathrm{NO}_{2}^{-}+\mathrm{H}^{+} \\
\mathrm{ArNO} \stackrel{\text { oxidation }}{\longrightarrow} \mathrm{ArNO}_{2} \\
\mathrm{~N}_{2} \mathrm{O}_{4}+\mathrm{ArH} \longrightarrow \mathrm{ArNO}_{2} \longrightarrow \mathrm{NO}_{2}^{-}+\mathrm{H}^{+}
\end{array}
$$


Retardation of rate by further increase in $\mathrm{pH}$ is due to decrease in the generation of $\mathrm{NO}_{2}{ }^{-}$radicals.

$$
{ }^{\bullet} \mathrm{OH}+\mathrm{NO}_{2}^{-} \longrightarrow \mathrm{NO}_{2}{ }^{-}+\mathrm{OH}^{-}
$$

Increase in $\mathrm{pH}$ will add more $\mathrm{OH}^{-}$ions to the solution. It will retard the reaction (6) and as a consequence, the formation of $\mathrm{NO}_{2}{ }^{\bullet}$ radicals also. Hence there will be a corresponding decrease in the rate of reaction.

\section{Effect of nitrite ion concentration}

Effect of nitrite ion concentration on the rate of reaction is investigated and results are given in Table 3. It is observed that the rate of reaction increases with the increase in nitrite concentration upto a certain limit, i.e. $2 \cdot 4 \cdot 10^{-3} \mathrm{M}$ for both phenol and salicylic acids. After this, a further increase in concentration of nitrite ion adversely affects the rate of reaction.

Table 3

\section{Effect of sodium nitrite concentration}

\begin{tabular}{|c|c|c|}
\hline \multicolumn{2}{|c|}{$\begin{array}{l}\text { Phenol } \\
{\left[\begin{array}{l}\text { Phenol }]=3.2 \cdot 10^{-3} \mathrm{M} \\
\text { pH }=5.5 \\
\mathrm{HCOONa}=3.2 \cdot 10^{-4} \mathrm{M}\end{array}\right.}\end{array}$} & $\begin{array}{l}\text { Salicylic acid } \\
{[\text { Salicylic acid }]=2.8 \cdot 10^{-3} \mathrm{M}} \\
\mathrm{pH}=5.0 \\
\mathrm{HCOONa}=2.4 \cdot 10^{-4} \mathrm{M}\end{array}$ \\
\hline$\left[\mathrm{NaNO}_{2}\right] \cdot 10^{3} \mathrm{M}$ & $\begin{array}{l}k \cdot 10^{4} \mathrm{~s}^{-1} \\
\text { (Phenol) }\end{array}$ & $\begin{array}{c}k \cdot 10^{3} \mathrm{~s}^{-1} \\
\text { (Salicylic acid) }\end{array}$ \\
\hline 2.0 & 3.14 & 3.40 \\
\hline 2.4 & 12.79 & 7.08 \\
\hline 2.8 & 9.45 & 4.36 \\
\hline 3.2 & 9.17 & 4.28 \\
\hline 3.6 & 7.00 & 4.06 \\
\hline
\end{tabular}

As the concentration of sodium nitrite is increased, more $\mathrm{NO}_{2}{ }^{-}$ions are available for excitation and consecutive generation of $\mathrm{NO}_{2}{ }^{-}$radicals and hence, the rate of reaction increases but after a certain limit, these nitrite ions will hinder their own movement, which in turn, will decrease the rate of reaction.

\section{Effect of formate ion concentration}

As the formate ions are $\mathrm{OH}^{\bullet}$ radical scavenger and therefore, the photochemical nitration is carried out in the presence and absence of fomate ions. It is observed that the rate of photochemical reaction increases rapidly in the presence of formate ions. It is so because $\mathrm{OH}^{\bullet}$ radicals are scavenged by formate ions making more $\mathrm{NO}_{2}{ }^{\bullet}$ radicals available for nitration. Moreover, $\mathrm{OH}^{\bullet}$ radicals also decrease the concentration of $\mathrm{NO}_{2}{ }^{\bullet}$ radicals according to the equation (8). The results are reported in Table 4.

$$
\begin{aligned}
\mathrm{HCOO}^{-}+\cdot & \mathrm{OH} \longrightarrow \mathrm{CO}_{2}^{-}+\mathrm{H}_{2} \mathrm{O} \\
\mathrm{OH}^{\bullet}+\mathrm{NO}_{2} & \longrightarrow \mathrm{NO}_{3}^{-}+\mathrm{H}^{+}
\end{aligned}
$$

Table 4

Effect of formate ion concentration

\begin{tabular}{ccc}
\hline \hline $\begin{array}{l}\text { Phenol } \\
{[\text { Phenol }]=3.2 \cdot 10^{-3} \mathrm{M}} \\
\mathrm{pH}=5.5 \\
\mathrm{NaNO}_{2}=2.4 \cdot 10^{-3} \mathrm{M}\end{array}$ & $\begin{array}{l}\text { Salicylic acid } \\
{[\text { Salicylic acid }]=2.8 \cdot 10^{-3} \mathrm{M}} \\
\mathrm{pH}=5.0 \\
\mathrm{NaNO}_{2}=2.4 \cdot 10^{-3} \mathrm{M}\end{array}$ \\
\hline$\left[\mathrm{HCOONa} \cdot 10^{4} \mathrm{M}\right.$ & $\begin{array}{c}\mathrm{k} \cdot 10^{4} \mathrm{~s}^{-1} \\
(\mathrm{Phenol})\end{array}$ & $\begin{array}{c}\mathrm{k} \cdot 10^{3} \mathrm{~s}^{-1} \\
(\text { Salicylic acid })\end{array}$ \\
\hline 2.0 & 8.81 & 6.34 \\
2.4 & 10.96 & 7.08 \\
2.8 & 12.49 & 6.43 \\
3.2 & 12.79 & 6.26 \\
3.6 & 8.84 & 6.10 \\
\hline \hline
\end{tabular}

\section{Effect of phenol and salicylic acid concentration}

The effect of the change in concentration of both phenol and salicylic acid on the rate of reaction is also studied and the results are presented in Table 5.

As the concentration of phenol and salicylic acid is increased, the rate of reaction increases upto a certain limit, i.e. $3 \cdot 2 \cdot 10^{-3} \mathrm{M}$ for phenol and $2.8 \cdot 10^{-3} \mathrm{M}$ for salicylic acid. After this, further increase in concentration results in a decrease in the rate of reaction. At higher concentration phe- 
nol and salicylic acid themselves act as filters due to their dark colors. Hence, they will not permit the desired light intensity to reach the molecules present in the bulk of solution and as a result, the reaction rate is retarded.

Table 5

Effect of phenol and salicylic acid concentration

\begin{tabular}{ccc}
\hline $\begin{array}{l}\text { Phenol } \\
\mathrm{pH}=5.5\end{array}$ & \multicolumn{2}{l}{$\begin{array}{l}\text { Salicylic acid } \\
\mathrm{pH}=5.0\end{array}$} \\
$\begin{array}{l}\mathrm{NaNO}_{2}=2.4 \cdot 10^{-3} \mathrm{M} \\
\mathrm{HCOONa}=3.2 \cdot 10^{-4} \mathrm{M}\end{array}$ & & $\begin{array}{l}\mathrm{HCOONa}_{2}=2.4 \cdot 10^{-3} \mathrm{M} \\
\mathrm{HCO}^{-4} \mathrm{M}\end{array}$ \\
\hline$[$ Compounds $] \cdot 10^{3} \mathrm{M}$ & $\begin{array}{c}\mathrm{k} \cdot 10^{4} \mathrm{~s}^{-1} \\
(\mathrm{Phenol})\end{array}$ & $\begin{array}{c}\mathrm{k} \cdot 10^{3} \mathrm{~s}^{-1} \\
(\text { Salicylic acid })\end{array}$ \\
\hline 2.0 & 4.93 & 1.86 \\
2.4 & 7.08 & 2.39 \\
2.8 & 6.39 & 7.08 \\
3.2 & 12.79 & 5.78 \\
3.6 & 10.53 & 5.27 \\
\hline \hline
\end{tabular}

\section{Identification of products}

The major products are identified as 4-nitrobenzene-1,2-diol and nitrososalicylic acid.<smiles>O=[N+]([O-])c1ccc(O)c(O)c1</smiles>

$\mathrm{m} / \mathrm{e}=155$<smiles>O=C(O)c1ccc([N+](=O)[O-])cc1</smiles>

$\mathrm{m} / \mathrm{e}=167$
Although formate ions are used as ${ }^{\circ} \mathrm{OH}$ radical scavengers in order to increase the rate of nitration, ${ }^{\circ} \mathrm{OH}$ radicals are very reactive and higher in concentration than $\mathrm{NO}_{2}{ }^{\bullet}$ radicals, therefore $-\mathrm{OH}$ groups are also introduced in the ring even in the presence of formate ions. The nitroso group $(-\mathrm{NO})$ has also been introduced into the ring on reaction with $\mathrm{N}_{2} \mathrm{O}_{3}$.

The minor products of salicylic acid (I \& II) and phenol (III, IV \& V) are also obtained and characterized by GC-MS as-<smiles>O=C(O)c1ccc([N+](=O)[O-])cc1O</smiles$\mathrm{m} / \mathrm{e}=183$

(I)<smiles>O=C(O)c1ccc(O)cc1O</smiles>

$\mathrm{m} / \mathrm{e}=154$

(II)<smiles>O=[N+]([O-])c1ccc(O)cc1</smiles>

$\mathrm{m} / \mathrm{e}=123$

(III)<smiles>Oc1ccccc1O</smiles>

$\mathrm{m} / \mathrm{e}=110$

(IV)<smiles>O=[N+]([O-])c1ccccc1O</smiles>

$\mathrm{m} / \mathrm{e}=139$ (V)

\section{Mechanism}

On the basis of the observed data, a tentative mechanism has been proposed for the nitration of aromatic compounds.

$$
\begin{aligned}
& \mathrm{NO}_{2}^{-} \stackrel{h v}{\longrightarrow}\left[\mathrm{NO}_{2}^{-}\right]^{*} \\
& {\left[\mathrm{NO}_{2}{ }^{-}\right]^{*} \longrightarrow \mathrm{NO}^{\bullet}+\mathrm{O}^{\bullet-}} \\
& \mathrm{O}^{\bullet-}+\mathrm{H}_{2} \mathrm{O} \longrightarrow{ }^{\bullet} \mathrm{OH}+\mathrm{OH}^{-} \\
& 2^{\bullet} \mathrm{OH}+\mathrm{NO}^{\bullet} \longrightarrow \mathrm{NO}_{2}{ }^{\bullet}+\mathrm{H}_{2} \mathrm{O} \\
& { }^{\circ} \mathrm{OH}+\mathrm{NO}_{2}^{-} \longrightarrow \mathrm{NO}_{2}{ }^{-}+\mathrm{OH}^{-}
\end{aligned}
$$
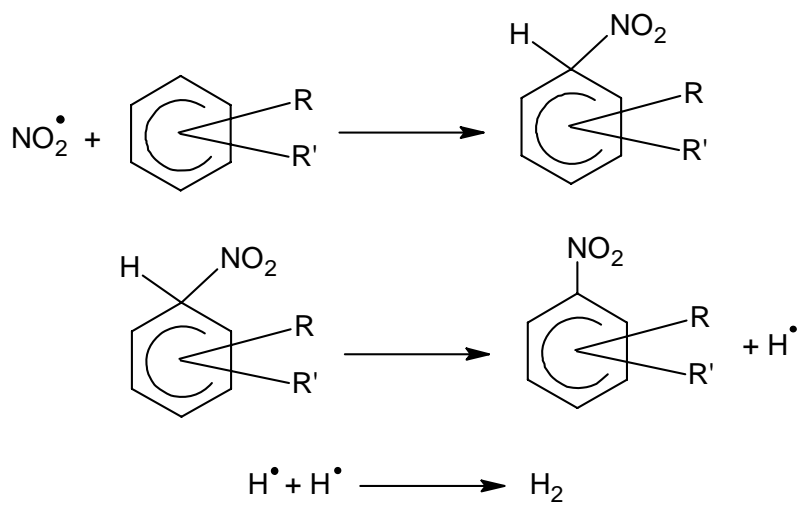

$\mathrm{R}=-\mathrm{OH} \& \mathrm{R}^{\prime}=-\mathrm{H}$ (in phenol)

$\mathrm{R}=-\mathrm{COOH} \& \mathrm{R}^{\prime}=-\mathrm{OH}$ (in salicylic acid)

Nitrite ion absorbs radiation of suitable wavelength and get excited. This ecited nitrite ion dissociates into $\mathrm{NO}^{\bullet}$ radicals and $\mathrm{O}^{\bullet}$ radical anion. This radical anion decomposes water to give $\mathrm{HO}^{\circ}$ radicals and $\mathrm{OH}^{-}$ion. The $\mathrm{HO}^{\circ}$ radical may react 
with $\mathrm{NO}^{\bullet}$ radical to generate $\mathrm{NO}_{2}^{\bullet}$ radical which may also undergo in case of recombination reaction giving nitrite ion. This step seems to dominate in higher $\mathrm{pH}$ range. $\mathrm{NO}_{2}{ }^{-}$radicals now attack the aromatic moiety giving nitro derivatives.

\section{CONCLUSION}

Ordinary nitration of aromatic systems is accompanied by hazardous brown fumes of $\mathrm{NO}_{2}$ gas, which adds environmental pollution. The present work provides a facile route for their process, i.e. nitration. However, the yield of the product does not react the desired extent, but photochemical nitration of aromatic systems by alkalinitrites will provide an ecofriendly route and the rate of the reaction may be increased in years to come to make this process commercially viable.

Acknowledgement: Authors are thankful to the Head of the Chemistry Department, Mohanlal Sukhadia University, Udaipur.

\section{REFERENCES}

[1] W. H. Glaze, J. W. Kang, D. H. Chapin, The chemistry of water treatment processes involving ozone, $\mathrm{H}_{2} \mathrm{O}_{2}$ and ultraviolet radiation, Ozone: Sci. Engineering, 9, 335-352 (1987).

[2] S. Selzer, F. Lam, L. Packer, Photonitration of phenols by tetranitromethane under visible light. J. Am. Chem. Soc., 104, 6470-6471 (1982).

[3] D. Vione, V. Maurino, C. Minero, M. Vincenti, E. Pelizzeti, Aromatic photonitration in homogeneous and heterogeneous aqueous systems, Environ. Sci. Pollut. Res. Int., 10, 321-324 (2003).

[4] S. Nelieu, L. Kerhoas, M. V. Shankar, J. Einhorn, Phototransformation of monuron induced by nitrate and nitrite ions in water: Contribution of photonitration, J. Photochem. Photobiol. A, 193, 1-9 (2008).

[5] A. Lalitha, K. Sivakumar, Zeolite H-Y-supported copper(ii) nitrate: a simple and effective solid-supported reagent for nitration of phenols and their derivatives, Synthetic Commun., 38, 1745 - 1752 (2008).
[6] N. Matykiewiczova, R. Kurkova, J. Klanova, P. Klan, Photochemically induced nitration and hydroxylation of organic aromatic compounds in the presence of nitrate or nitrite in ice, J. Photochem. Photobiol., 187A, 24-32 (2007).

[7] M. A. Zolfigol, B. F. Mirjalili, A. Bamoniri, M. A. K. Zarchi, A. Zarei, L. Khazdooz, J. Noei, Nitration of aromatic compounds on silica sulphuric acid, Bull. Korean Chem. Soc., 25, 1414-1416 (2004).

[8] S. Rajender Varma, P. Kannan Naicker, J. P. Liesen, Selective nitration of styrenes with clayfen and clayan: A solvent-free synthesis of $\beta$-nitrostyrenes, Tetrahedron Letters, 39, 3977-3980 (1998).

[9] T. Beitz, W. Bechmann, R. Mitzner, Investigation on the photoreaction of nitrate and nitrite ions with selected azaarenes in water, Chemosphere, 38, 351-361 (1999).

[10] V. M. Nagaev, G. A. Sorol Skii, S. S. Khokhhov, A. F. Eleev, Direct N-nitration of bis(trifluoromethyl)-containing 2-azanorbornanes, Russian Chem. Bulletin., 52, 2285-2286 (2003).

[11] Y. Kono, T. Yamasaki, A. Ueda, H. Shibata, Catalase catalyzes of peroxynitrite-mediated phenolic nitration, Biosci. Biotechol. Biochem., 62, 448-452 (1998).

[12] S. P. Degade, S. B. Waghmode, V. S. Kadam, M. K. Dongare, Vapor phase nitration of toluene using dilute nitric acid and molecular modeling studies over beta zeolite, Appl. Catal., 226, 49-61 (2002).

[13] C. Desroches, S. Parola, F. Vocanson, M. Perrin, R. Lamartine, J. M. Letoffe, J. Bouix, Nitration of thiacalix[4]arene using nitrosium nitrate complexes: synthesis and characterization of tetranitro-, and tetra(4-pyridylimino) tetrahydroxythiacalix [4]arene, New J. Chem., 26, 651655 (2002).

[14] T. Yamato, K. Tsuchihashi, N. Nakamura, M. Hirahara, H. T. Suzuki, Medium-sized cyclophanes, part 59:1 Nitration of [3.3]- and [3.3.3]-metacyclophanes. Through-space electronic interactions between two or three benzene rings, Can. J. Chem., 80, 207-215 (2002).

[15] Y. Usui, S. Takebayashi, M. Takeuchi, Photochemical nitration of benzoic acid derivatives by irradiation to nitrate ions, Bull. Chem. Soc. Japan, 65, 3183-3185 (1992).

[16] M. Fisher, P. Warneck, Photodecomposition of nitrite and undissociated nitrous acid in aqueous solution, $J$. Phys. Chem., 100, 18749-18756 (1996).

[17] T. Arakaki, T. Migake, T. Hirakawa, H. Sakugawa, pH dependent photoformation of hydroxyl radical and absorbance of aqueous-phase $\mathrm{N}(\mathrm{III})\left(\mathrm{HNO}_{2}\right.$ and $\left.\mathrm{NO}_{2}{ }^{-}\right)$, Environ. Sci. Technol., 33, 2561-2565 (1999). 